\title{
A new subspecies of Dorcadion fulvum (ScOPOLI, 1763) (Coleoptera: Cerambycidae) from western Ukraine
}

\author{
Andrew M. ZAMOROKA ${ }^{1,2 *}$ \\ ${ }^{1}$ Department of Biology and Ecology, Vasyl Stefanyk Precarpathian National University, \\ Shevchenko str., 57, Ivano-Frankivsk, Ukraine \\ ${ }^{2}$ Halych National Park, Lvivska str., 1, Krylos, Ivano-Frankivsk Region, Ukraine
}

\begin{abstract}
This study provides a description of Dorcadion fulvum opillicum ssp. nov., which is the fourth subspecies of the central European species Dorcadion fulvum (SCOPOLI, 1763). The new subspecies was compared with its closest relative, Dorcadion fulvum erythropterum FISCHER VON WALDHEIM, 1823. A differential diagnosis and a key to taxa identification are provided. The distribution of all four subspecies of D. fulvum was clarified and mapped with comments on the most contradictory published data.
\end{abstract}

KEY WORDS: new taxa, Dorcadion fulvum opillicum ssp. nov., longhorn beetles, Opillya steppes

\section{INTRODUCTION}

Since Breuning's revision of Dorcadionini, three subspecies of Dorcadion fulvum (SCOPOLI, 1763) have been recognized (BREUNING 1962): Dorcadion fulvum fulvum (SCOPOLI, 1763), Dorcadion fulvum cervae FRIVALDSZKY, 1892 and Dorcadion fulvum canaliculatum FisCHER-WALDHEIM, 1823. LÖBL \& SMETANA (2010) accepted D. $f$. canaliculatum as a synonym of Dorcadion fulvum erythropterum FISCHER VON WALDHEIM, 1824. The same authors also recognized D. f. cervae as a distinct species, Dorcadion cervae FRIVALDSZKY, 1892. However, a comparison of the mitochondrial cytochrome c oxidase gene subunit I (COI) sequences obtained from $D . f$. cervae and $D . f$. fulvum revealed similar sequence patterns between these two taxa (MERKL et al. 2007). These findings by MERKL et al. (2007) support the idea that D. cervae is a subspecies of D. fulvum.

\footnotetext{
* Corresponding author: andrii.zamoroka@pu.if.ua
} 
In this study I discuss three subspecies of D. fulvum: D. f. fulvum, D. f. cervae, D. $f$. erythropterum and provide a description of a fourth subspecies $D$. f. opillicum ssp. nov.

\section{MATERIALS AND METHODS}

This study is based on my own materials, as well as those deposited in the collections of scientific institutions (Vasyl Stefanyk Precarpathian National University (PNU), Halych National Park (HNP), State Museum of Natural History (SMNH), Nature Reserve "Medobory" (NRM), State Museum of Nature of the V. N. Karazin Kharkiv National University (SMNKNU)) and the private collections of Mr Ruslan PANIN (RP) and $\mathrm{Mr}$ Oleksander KRAVCHENKO (OK).

Comparative material: 101 19.06.2018, the village of Kopachyntsi, Horodenka distr., Ivano-Frankivsk Reg., Ukraine, coll. A. ZAMOROKA (AZ); $3 \hat{\jmath} \widehat{\partial} 5$ 우우 11.05.2010, $2 \hat{\widehat{\partial}} \widehat{\partial}$ 25.05.2016, loc. "Tovtra Dovha", the village of Vikno, Husyatyn distr., Ternopil Reg., Ukraine, coll. Ya. KAPELYUKH (NRM); 101 1 09.05 .2010 , near the town of Berezivka, Odessa Reg., coll. O. KravCHENKO (OK); 101 1 09.06.2007, the village of Holohirky, Zolochiv distr., Lviv Reg, Ukraine, coll. R. PANIN (RP); 5 스새 3 우우 20.06.2004, near the

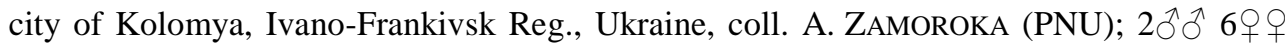
15.06.2001, "Vovchynetski Hory", near the city of Ivano-Frankivsk, Ivano-Frankivsk Reg., Ukraine, coll. A. ZAMOROKA (PNU); 1 undated $\widehat{\partial}$, loc. "Haydamatskyi Yar", the village of Busha, Yampil distr., Vinnytsya Reg., Ukraine, coll. D. KURINNYI (RP); 1 undated $\uparrow$, near the city of Odesa, Ukraine, coll. A. HONTARENKO (OK); 1 undated specimen, the village of Ivankiv, Borschiv distr.; 1 undated specimen, the village of Derenivka, Terebollya distr., Ternopil Reg., Ukraine (SMNH).

The holotype $\left(1 \delta^{\Uparrow}\right)$ and 3 paratypes $\left(1 \delta^{\Uparrow}\right.$ and 2 웅) are deposited in the PNU collection;

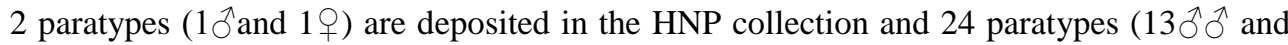
11 우우) are preserved in the author's collection (AZ).

The habitus photographs of the entire beetles and their parts were taken using a DLTCam PRO 5 MP USB camera attached to a Nikon SMZ-1 stereomicroscope at $40 \times$ magnification. Images were then aligned and stacked in the DLTCamViewer x86, 3.7.7892 software package and enhanced in Adobe Photoshop CS3 v. 10.0. 


\section{RESULTS}

\section{Type material}

Holotype: $1 \widehat{\jmath}$ 19.06.2015, loc. "Kuropatnytskyi Kamin" (49.286027N, 24.669622E), the village of Kuropatnyky, Halych distr., Ivano-Frankivsk Reg., Ukraine, coll. A. ZAMOROKA (PNU).

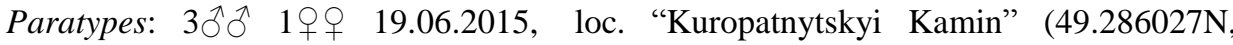
24.669622E), the village of Kuropatnyky, Halych distr., Ivano-Frankivsk Reg., Ukraine,

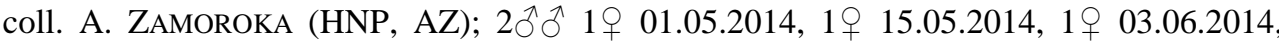
$3 \widehat{\jmath}$ 17.06.2014, 1ठ 19.05.2017, loc. "Kasova Hora" (49.224686N, 24.695037E), the village of Bovshiv, Halych distr., Ivano-Frankivsk Reg., Ukraine, coll. A. ZAMOROKA (AZ); $1 ð 2$ 우 18.04.2014, $1 ð 15.08 .2014$, loc. "Simlyn" (49.167999N, 24.839748E), the village of Yabluniv, Halych distr., Ivano-Frankivsk Reg., Ukraine, coll. A. ZAMOROKA

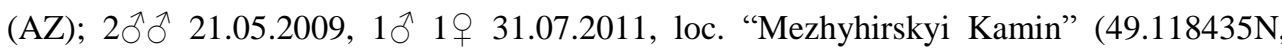
24.803611E), the village of Mezhyhirtsi, Halych distr., Ivano-Frankivsk Reg., Ukraine,

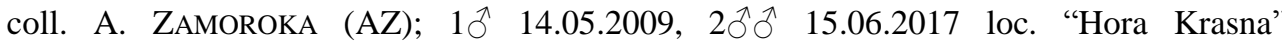
(49.240624N, 24.815721E), the village of Stari Skomorokhy, Halych distr., IvanoFrankivsk Reg., Ukraine, coll. A. ZAMOROKA (AZ).

\section{Description}

Dorcadion fulvum opillicum ssp. nov.

Holotype: male (Fig. 1A, 1C). Body size $22 \mathrm{~mm}$. Body subcylindrical, moderately elongate. Integuments black with a brownish tint, densely covered with fine hairs.

Head with long median sulcus (Fig. 2A), densely covered with pale hairs and with two longitudinal dark brown stripes. Occiput very convex, forming a lump (Fig. 1C) with fine punctation and dust-like hair cover. Frons trapezoidal with rough punctation. Genae and temples smooth, with sparse deep punctures and dust-like hair cover. Labrum long, notched in the middle, and covered with dense hair with bunches of long tough setae. Labrum covers half of mandibles. Antennae black, except for first antennomere, which is dark brown. Narrow longitudinal area on first antennomere covered with short stiff hairs.

Prothorax subcylindrical with lateral spines. Pronotum square. Pronotal median furrow wide and deep, with dense and rough punctation, covered by dust-like hairs. Both sides of furrow glabrous and lustrous, sparsely punctated. Sides and base of pronotum densely covered with deep and coarse punctation, as well as dust-like hairs. Scutellar shield elongate, trapezoidal with median longitudinal depression. Prosternum, mesosternum and metasternum uniformly black, dull, densely and finely punctated, covered with dense short hairs.

Legs dark brown and densely covered with stiff, brush-like yellowish hairs. 

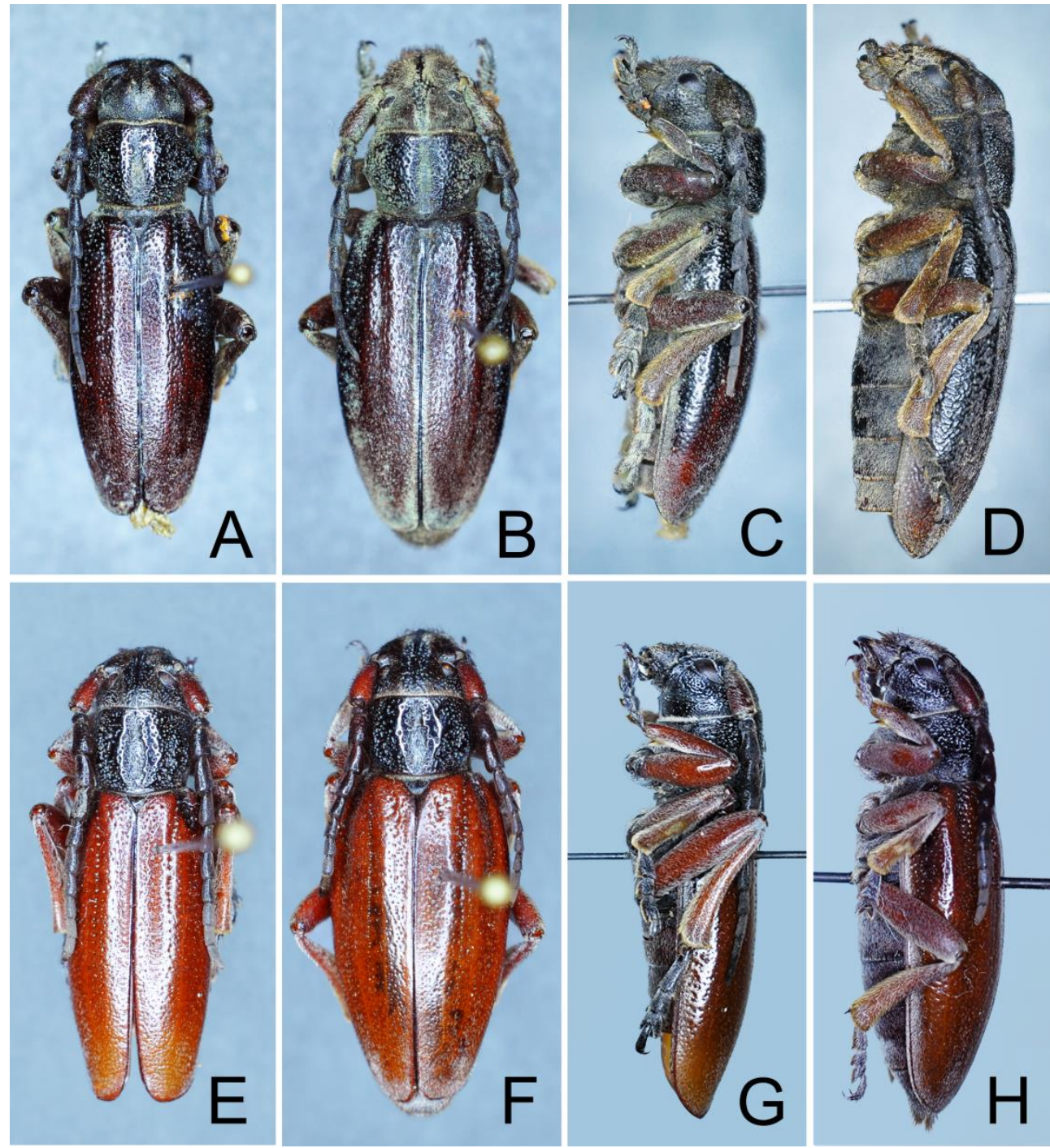

Fig. 1. Comparison of Dorcadion fulvum opillicum ssp. nov.: holotype (male) - A dorsal and $\mathbf{C}$ lateral view; allotype (female) - B dorsal and D lateral view; D. fulvum erythropterum (Berezivka, Odesa Reg.): male $-\mathbf{E}$ dorsal and $\mathbf{G}$ lateral view; female $-\mathbf{F}$ dorsal and $\mathbf{H}$ lateral view. 

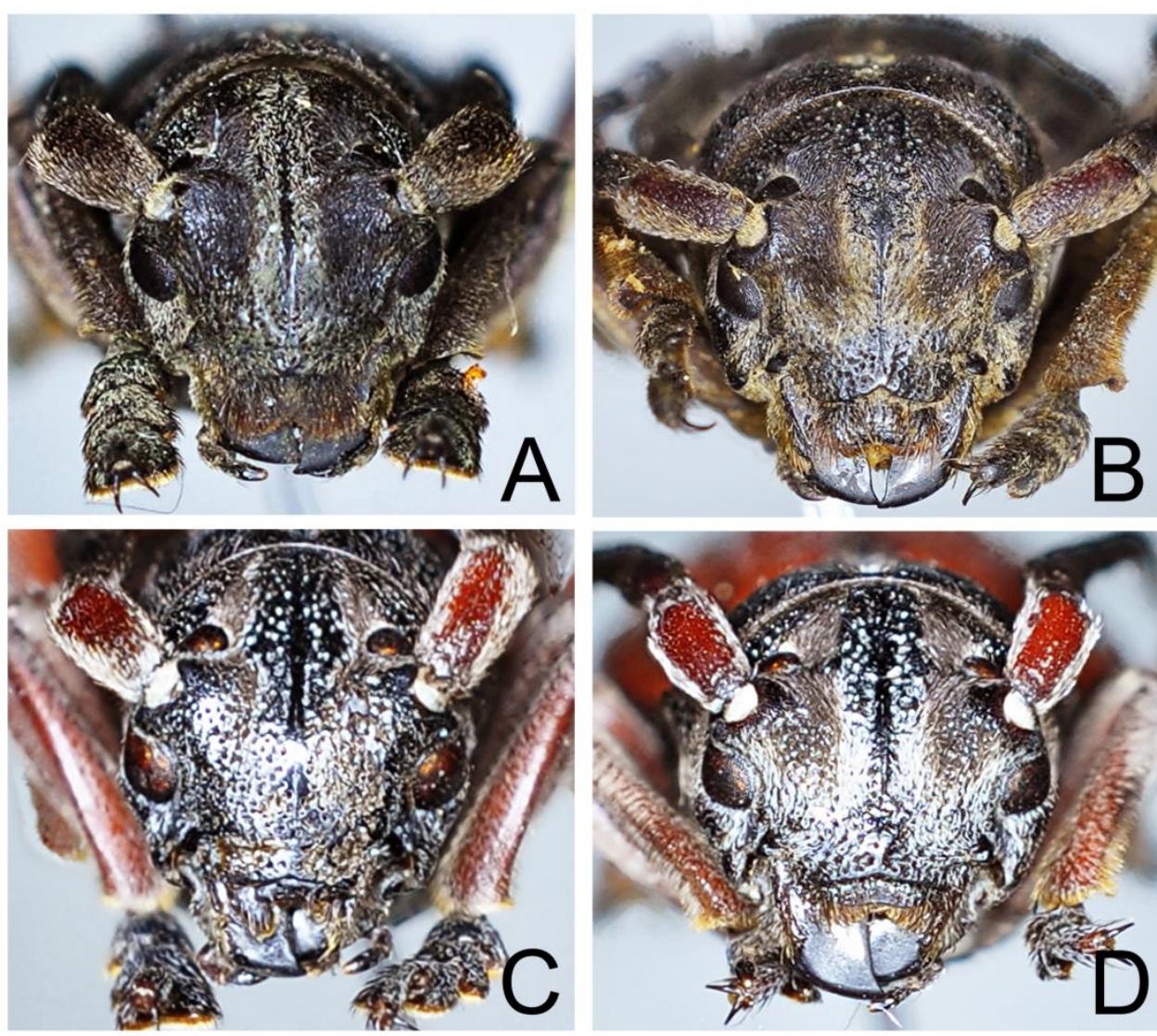

Fig. 2. Frontal view of the head of Dorcadion fulvum opillicum ssp. nov.: A holotype (male) and B allotype (female); D. fulvum erythropterum (Berezivka, Odesa Reg.) C male and $\mathbf{D}$ female.

Elytra elliptical, widest in the middle, apex rounded. Colouration varies from dark brown on disc to black on base and sides. Elytra covered with small dust-like hairs, densely punctated. Disc finely punctated, moderately lustrous; sides of elytra coarsely punctated and slightly rugose. Shoulders smooth. Humeral carinae well developed, extending to middle of elytra. Traces of dorsal carinae present on basal part of elytra.

Abdominal sternites uniformly black, moderately lustrous with very fine but sparse punctation, densely covered with dust-like hairs. Apex of fifth sternite with a small depression. 


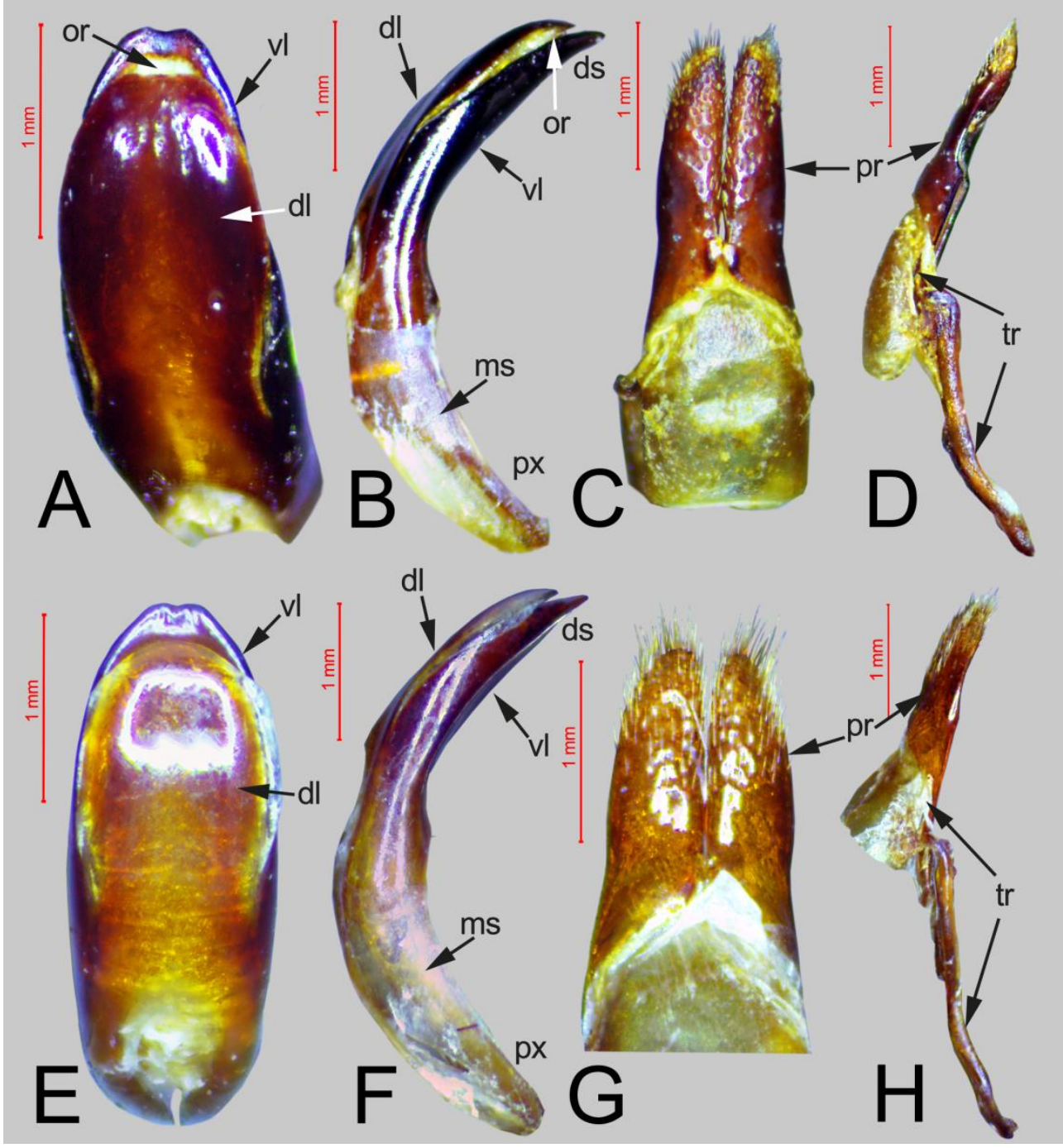

Fig. 3. Comparison of male genitalia: Dorcadion fulvum opillicum ssp. nov. (holotype) - A dorsal and $\mathbf{B}$ lateral view of the aedeagus, $\mathbf{C}$ dorsal view of the parameres, $\mathbf{D}$ lateral view of the entire tegmen; D. fulvum erythropterum (Berezivka, Odessa Reg.) - E dorsal and $\mathbf{F}$ lateral view of the aedeagus, $\mathbf{G}$ dorsal view of the parameres, $\mathbf{H}$ lateral view of the entire tegmen. Abbreviations: px - proximal part, ds - distal part, ms - median struts, $\mathbf{d l}$ - dorsal lobe, $\mathbf{v l}$ - ventral lobe, or - orificium, $\mathbf{p r}$ - parameres, $\mathbf{t r}$ - tegminal ring. 
Genitalia. Median lobe of aedeagus robust, well sclerotized and curved (Fig. 3A, 3B). Proximal (median struts - ms) and distal parts (both dorsal - $\mathrm{dl}$ and ventral lobes $-\mathrm{vl}$ ) of equal length. Dorsal lobe is shovel-shaped, tapering slightly apical and apically truncated, length $2 / 3$ that of ventral lobe. Ventral lobe distinctly longer than apex of dorsal lobe; hence, orificium (or) visible from dorsal side of aedeagus. Apex of ventral lobe moderately notched, its margins thickly sclerotized. Tegmen elongated (Fig. 3C, 3D), its parameres (pr) nearly as long as tegminal ring (tr). Parameres long and narrow, coarsely punctated on internal and apical sides and covered with short hairs.

Allotype. For this description I selected 1 female (Fig. 1B, 1D), labelled "Paratype 1", which is deposited in the collection of PNU. The body (length $23 \mathrm{~mm}$ ) is more robustly sculptured than in the male holotype.

The female allotype resembles the male holotype except for the characteristic patterns of the head, pronotum and elytra. The female's head is wider (Fig. 2B). The pronotum is transverse, and is wider than long. The elytra have very robust shoulders, which protrude as far as the pronotal lateral spines. The strong and very well developed humeral carinae run down both sides of the elytra, starting from the shoulders and covering at least two-thirds of the elytra. The dorsal carinae are better developed than in the male. The elytra are coarsely punctated, rugose, and are less lustrous than in the holotype.

Variations. The size and colouration of D.f. opillicum ssp. nov. vary among the population. The elytra in at least $27 \%$ of the examined specimens $(n=8)$ had a completely $(20 \%)$ or partly $(7 \%)$ pale colouration. The remainder, i.e. $73 \%(\mathrm{n}=22)$ of the specimens, were dark in colour. The body length in the males varies from 18 to $23 \mathrm{~mm}$ (mean $=20.1$ $\mathrm{mm}(\mathrm{n}=16))$ and in the females from 20 to $24 \mathrm{~mm}($ mean $=22 \mathrm{~mm}(\mathrm{n}=14))$.

Etymology. The new subspecies is named after the physiographic region of Opillya (western Ukraine), where it was collected.

Type locality. "Kuropatnytskyi Kamin" (49.286027N, 24.669622E), 291 m a.s.1., near the village of Kuropatnyky, Halych district, Ivano-Frankivsk Region, Ukraine.

Habitat. D. f. opillicum ssp. nov. inhabits xerophilous steppe localities on the roughly rectangular, flat-topped hills with often karstified (i.e. karstic funnels, sinkholes, deep ravines, rocky outcrops, ponors etc.) steep slopes. The soil is rich in gypsum. D. f. opillicum ssp. nov. is recorded in various steppe vegetation communities. These include Brachypodietalia pinnati KORNECK, 1974, present on the flat-topped hills, summits and gentle slopes, and Festucetalia valesiacae Soó, 1947, found on the steep south-facing slopes of the hills covered with a thin layer of soil and crushed gypsum stones.

Differential diagnosis. Dorcadion fulvum opillicum ssp. nov. differs from the other three subspecies of Dorcadion fulvum (i.e. D. f. fulvum, D.f. cervae, D. f. erythropterum) by the very robust body sculpture that includes coarse and rugose punctation, well developed humeral carinae, dense hair coverage and genitalia morphology. The body shape 
of D.f. opillicum ssp. nov. more closely resembles Dorcadion carinatum igrenum DANILEVSKY, 1998 (specifically, the form with red legs and fulvous elytra), although the genitalia are completely different (not shown here) from those of the geographically closest subspecies D.f.erythropterum. The main diagnostic features of Dorcadion fulvum opillicum ssp. nov. include the size of the labrum, shape of the occiput, shape of scutellum, elytral sculpture, and male genitalia morphology.

The dominant colouration of $D$. f. opillicum ssp. nov. is black to dark brown on the elytra; it is rarely fulvous, as in the case of D.f.erythropterum. The labrum of D. f. opillicum ssp. nov. is long and covers at least $1 / 2$ of the mandible (Fig. 2A, 2B), whereas in D. f. erythropterum it is short and covers $1 / 5-1 / 4$ of the mandible (Fig. 2C, 2D). In contrast to D.f. erythropterum, where the occiput is nearly flat, the occiput of D. f. opillicum ssp. nov. is prominent and convex. The scutellum of D. f. opillicum ssp. nov. is elongate and with a median depression, whereas in D. f. erythropterum it is short, triangular and uniformly smooth. The elytra of $D$. f. opillicum ssp. nov. are very robustly sculptured. The most prominent features of the elytra are the well-developed, long humeral carinae and big shoulders (Fig. 2A, 2B), especially in the females (as in D. carinatum igrenum); in D. f. erythropterum these are smooth (Fig. 2E, 2F, 2H). Both subspecies differ in punctation: the elytra of D. f. erythropterum are lustrous, sparsely and finely punctated, whereas the elytral surface of D.f. opillicum ssp. nov. is dimmed by dense coarse punctation and wrinkling. The male genitalia morphology differs significantly between the subspecies (Fig. 3). First of all, this involves the relative size of the proximal (px) and distal (ds) parts of the median lobe of the aedeagus: the ratio of the proximal part to the distal one is nearly 1:1 in D. f. opillicum ssp. nov. but is about 1.3:1 in D. f. erythropterum. The dorsal and ventral lobes of the aedeagus are bigger and longer in D. f. opillicum ssp. nov. with the apex truncated. The tegmen of D. f. opillicum ssp. nov. is different from that in D.f. erythropterum in several characters, including the paramere shape (elongate), punctation (punctated on the inner side, and from the base to the apex), hairs (short) coverage and the ratio of the length of the parameres to that of the tegminal ring (nearly 1:1 in D. f. opillicum ssp. nov. and 1:2 in D. f. erythropterum). Also, the average body length of D. f. opillicum ssp. nov. is larger (males $20.1 \mathrm{~mm}$, females $22 \mathrm{~mm}$ ) in comparison with D. f. erythropterum (males $17.9 \mathrm{~mm}$, females $19.5 \mathrm{~mm}$ ).

Key to Dorcadion fulvum subspecies, including $D$. carinatum and D. aethiops in Europe

1 (12) Pronotum coarsely punctated, medial furrow present. . . . . . . . . .

2 (5) Humeral carinae clearly and strongly pronounced, as long as $3 / 4$ of the elytral length. Elytra weakly convex, almost flattened. 15-24. Distribution east of the River Dnipro (Dnieper) - Dorcadion carinatum (Pallas, 1771)............ 3. 
3 (4) Legs and body entire black. Body is robust. 17-24. Distribution east of the River Siverskyi Dinets. . . . . . . ssp. Dorcadion carinatum carinatum (PALlas, 1771).

4 (3) Legs and elytra partly brown or reddish. Body slender. 17-21. Distribution between the Rivers Dnipro and Siverskyi Dinets. . . . . . . . . . . . . ssp. Dorcadion carinatum igrenum DANILEVSKY, 1998.

5 (2) Humeral carinae partially smooth up to $2 / 3$ of elytral length. Elytra clearly convex. 15-24. Distribution from the Alps across the Balkan Peninsula to the River Dnipro.

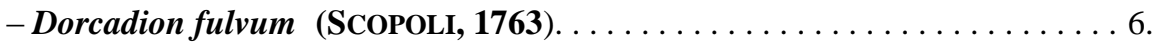

6 (9) Pronotal disc moderately punctated, medial furrow shallow. Elytral humerus

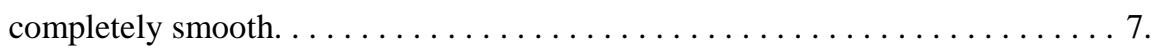

7 (8) Humeral carinae smooth for $1 / 3$ of elytral length. Body red-brown to black, elytra, legs and first antennomere bright red. 16-22. Distribution within the Pannonian Basin. . . . . . . . . . . . . . ssp. Dorcadion fulvum fulvum (SCOPOLI, 1763).

8 (7) Humeral carinae almost absent. Body entirely black with brownish tint. 15-18.

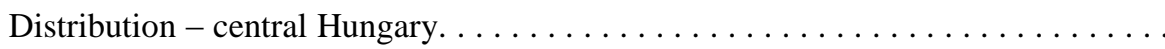
. . ssp. Dorcadion fulvum cervae FRIVALDZKY, 1892.

9 (6) Pronotal disc coarsely punctated, medial furrow deep. Elytral humerus clearly pronounced. . . . . . . . . . . . . . . . . . . . 10.

10 (11) Humeral carinae clearly pronounced, for $1 / 2$ elytral length. Elytra lustrous, sparsely punctated. Body red-brown to black, elytra, legs and first antennomere bright red. 16-22. Distribution in the Balkans and eastern Europe as far as the River Dnipro. . . . . . . . . . . . . . . . . . . . . . .... . . ssp. Dorcadion fulvum erythropterum FISCHER VON WALDHEIM, 1823.

11 (10) Humeral carinae strongly pronounced for 1/3 elytral length. Elytra coarsely and deeply punctated, rugose in female. Body dark brown to black, elytra, legs and first antennomere brownish. 18-24. Distribution within Opillya. . . . . . . . . . . $\ldots \ldots \ldots \ldots \ldots \ldots \ldots \ldots \ldots$ ssp. Dorcadion fulvum opillicum ssp. nov.

12 (1) Pronotal disc fine and sparsely punctated, medial furrow absent. Humeral carinae absent, elytra evenly convex, finely punctated. 15- 22. Entire body black. Distribution in the Pannonian Plain and the Balkan Peninsula. . . . . . . . . . .

Dorcadion aethiops (SCOPOLI, 1763).

\section{Distribution}

To date, D. $f$. opillicum ssp. nov. has been found in several localities within Opillya, the westernmost edge of the Podillya Upland (Fig. 4). However, the actual distribution range of D. f. opillicum ssp. nov. is unknown. The specimens from the surroundings of the city of Ivano-Frankivsk and Kolomya (the type locality for Dorcadion fulvum canaliculatum $m$. 


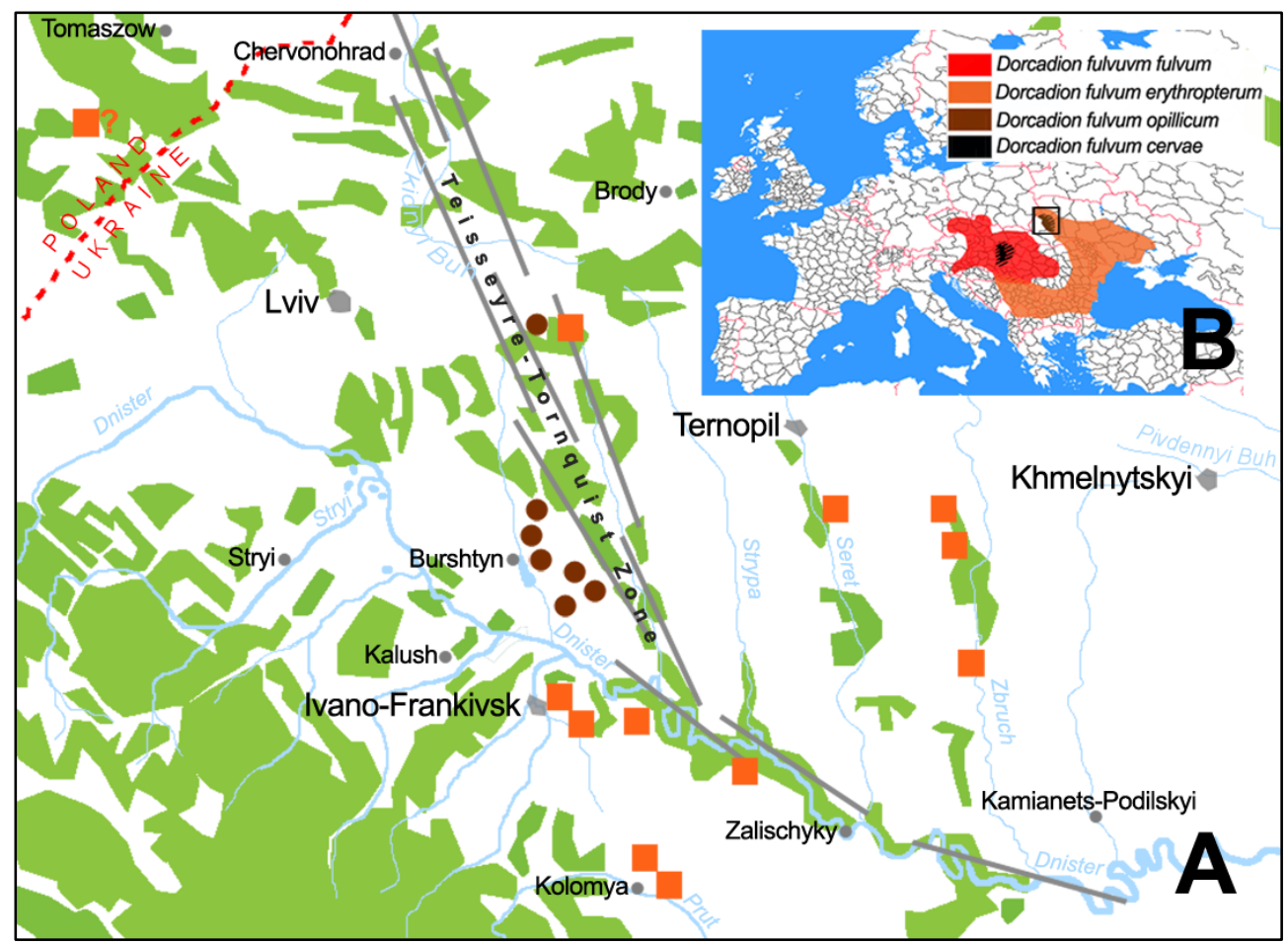

Fig. 4. Map showing the distribution of Dorcadion fulvum subspecies: A in western Ukraine and eastern Poland (circles - Dorcadion fulvum opillicum ssp. nov., squares - D. fulvum erythropterum); B in Europe.

humerocostatum BREUNING, 1946 (BREUNING 1946) $=$ D. f. erythropter[on]um (LÖBL \& SMETANA 2010) are similar to those from the vicinity of the city of Odesa and belong to D. f. erythropterum. Thus, the southern range limit of $D$. $f$. opillicum ssp. nov. probably lies in the valley of the River Dnister, north of Ivano-Frankivsk. Specimens obtained from the collection of the "Medobory" Nature Reserve (central Podillya Upland) also belong to $D . f$. erythropterum. In contrast, the specimens from Holohory (northern Podillya Upland) include both $D . f$. opillicum ssp. nov. and $D$. $f$. erythropterum as well as intermediate specimens. Therefore, the introgression zone of both subspecies lies to the east of Opillya. The most probable easternmost range boundary of $D$. f. opillicum ssp. nov. is the TeisseyreTornquist Zone, a narrow highland along the crustal boundary between the Phanerozoic orogens of south-western Europe and the Precambrian east European Craton. The Teisseyre-Tornquist Zone separates the westernmost part of the Podillya Upland and the Volyn Upland (both in Ukraine) and the Lublin Upland (Poland) from the rest of Podillya, 
where D. f. erythropterum is widespread. Unfortunately, the subspecific identity of $D$. fulvum from eastern Poland is unknown because of the lack of specimens for this study. In my opinion, it is likely to be $D$. $f$. opillicum ssp. nov., but additional studies will be needed.

Additionally, based on own materials and on published data, I clarified the distribution of all four subspecies of D. fulvum in Europe (Fig. 4). Special symbols designate the following: $*$ - the subspecies was originally not specified; the current assignment to a certain subspecies is based on geographical distribution; ? - the presence of a subspecies is not confirmed by certain collection data; (?) - the subspecies identity is doubtful according to current data.

Dorcadion fulvum opillicum ssp. nov.: Ukraine: Bovshiv, Burshtyn, Dytyatyn, Holohirky, Kukilnyky, Kuropatnyky, Mezhyhirtsi, Pukiv, Verkhnya Lypytsya, Yabluniv.

Dorcadion fulvum erythropterum: Albania: ?present (LÖBL \& SMETANA 2010); Bosnia and Herzegovina: ?present (LÖBL \& SMETANA 2010); Bulgaria: entire territory of Bulgaria (BREUNING 1962); Beledie Han*, Blagoevgrad*, Lozen*, Yundola*, Železnica; widespread throughout Bulgaria (GANEV 1985; GEORGIEV et al. 2006; MigLIACCIO et al. 2007; GEORGIEV 2011; TOPALOV et al. 2014); Croatia: ?present (LÖBL \& SMETANA 2010); Moldova: Bahmut*, Bender*, Calarasi*, Chisinau*, Cornesti*, Ermoclia, Razeni, SarataMereseni (CHYUBChIK 2010; SERAFIM \& MAICAN 2011); North Macedonia: ?present (LÖBl \& SMeTana 2010); Poland: (?)Klemensów*; (?)Machnów ad Tomaszów Lubelski* (BURAKOWSKI 1957; GUTOWSKI et al. 1999); Romania: widespread in Romania (BReuning 1962); Baile Herculane*, Beceni, Beciu*, Botosani*, Branesti*, Bucuresti*, Buzau, Canaraua Fetii*, Costesti*, Craiova, Daia, Drobeta-Turnu Severin, Dobrosloveni, Gaiseni*, Iaşi, Matasaru*, Izverna, Nicolae Titulescu, Podoleni*, Sabaoani*, Sabed, Sinaia*, Stejaru*, Suceava*, Tiganesti* (DASCALU 2006; Ungureanu et al. 2008; Serafim \& Chimisliu 2010; Serafim 2010; Serafim \& Maican 2011); Serbia: Banovo Polje, Belgrade, Crna Bara, Despotovac, Donja Sabanta, Fruska Gora, Jagodina, Jakovo*, Kragujevac, Obedska Bara, Opornica, Petrovac, Radenkovic, Ravnje, Rtanj, Šid, Šumarice, Soko Banja, Svilajnac, Strazilovo*, Tekija, Zagubica (ĆURČIĆ et al. 2003; PIL 2004/2005; Pil \& Stankovic 2006; Dascălu et al. 2012; Dobrosavljević \& MihaJlović 2014; ILIĆ \& ĆURČIĆ 2015; VUKAJLOVIĆ \& ŽIVANOVIĆ 2015); Ukraine: widespread in western and southern Ukraine (BREUnING 1962); Bakay, Berezivka, Bila Tserkva, Biloshapky, Busha, Chernelytsya, Derenivka, Ditkivtsi, Dzvenyhorod*, Holohirky, (?)Hutysko, Ivankiv, Ivano-Frankivsk, Kaniv, Khmeleva, Kolomya, Kopachyntsi, Kuripchyne, Myhiya, Nahirne, Odesa, Oleshiv, Petryliv, Pidhirtsi, Pysarivschyna, Rakovets, Skala-Podilska, Slovita, Synkiv*, Ternopil*, Tomylivka, Trakhtemyriv, Velyka Vilshanytsya, Verbivtsi, Vikno, Zalischyky* (BREUNING 1962; BARTENEV 2009; ZAMOROKA et al. 2012).

Dorcadion fulvum fulvum: Austria: widespread in eastern Austria; Steiermark, Wien (BReuning, 1962; BreliH et al. 2006; Lingafelter et al. 2014); Czech Republic: 
Bohemia, Litomysl, Morava (BREunING 1962); Hungary: widespread in Hungary (BREuNING 1962); Budakalász, Budakeszi, Budaörs, Budapest, Dömsöd, Dunaharaszti, Eger, Erd, Farmos, Fót, Gödöllo, Gyöngyös*, Gyöngyöspata*, Isaszeg, Karácsond*, Kitérőgyár*, Kölked, Mariagyud, Mátraháza*, Monok*, Nagybörzsöny, Nagykovácsi, Nagymaros, Pécel, Perocsény, Pilisvörösvár, Pomáz, Sátoraljaújhely*, Szeged*, Siklós, Solymár, Szentendre, Szob, Szucsi*, Tárnok, Tokaj*, Törökbálint, Tolcsva*, Veroce, Villany, Visegrád, Vokany, Zebegény (GASKó 1978; HoRVATOVICH 1992; MERKL et al. 1996; HegYessy \& KovÁCs 1997; KovÁCs \& HegYessy 1997; HegYessY et al. 2000; Horvatovich et al. 2000); Poland: (?)Raciborz* (BURAKOwSKI, 1957); Romania: Ban*, Cluj-Napoca*, Hașag*, Ocna Sibiului*, Nucet*, Șeica Mică*, Tarnaveni*, Turda*, Vingard* (ISTRATE 2005; SERAFIM 2010; DASCALU et al. 2012); Slovakia: widespread in Slovakia (BREUNING 1962); Kamenica*; Šturovo*; Tvrdošovce* (AISTLEITNER et al. 2015) Slovenia: Lenart, Vipava; possibly extinct in Slovenia (BRELIH et al. 2006); Ukraine: Uzhhorod* (FASULATI 1955).

Dorcadion fulvum cervae: Hungary: Akasztó, Apajpuszta, Budapest, Bugyi, Dömsöd, Dunatetétlen, Farmos, Felsőerek, Felső-Kiskunsági, Miklapuszta, Szabadszállás, Szigetcsép, Újsolt (HEGYESSY et al. 2000; MÁTÉ \& MERKL 2005).

According to the available data, D. f. fulvum inhabits the Pannonian Plain between the Alps in the west and the Carpathians in the east, including Ukraine and Romania. In the north its range reaches the Ore Mountains in the Czech Republic, south-western Poland and the Carpathian Mountains in Slovakia. The River Danube, a natural border preventing D. $f$. fulvum from spreading to the south, separates it from another subspecies, $D . f$. erythropterum. The presence of D. f. fulvum in Croatia is unclear: if it is present, then only in the north-east of the country as far as the River Drava. D. f. fulvum should also be present in the northernmost part of Serbia, but at present there are no confirmatory data.

Dorcadion fulvum cervae inhabits a spatially and ecologically very restricted area in central Hungary east of the Danube. This area represents the Pannonian solonchak habitats (MERKL et al. 2007).

South of the Danube we find D. f. erythropterum. Its range in the Balkan Peninsula is still unclear. LÖBL \& SMETANA (2010) and DANILEVSKY (2019) suggested that $D . f$. erythropterum should be present in Albania, Bosnia and Herzegovina, Croatia, and North Macedonia, but there is no confirmation of its presence there. It seems that the range of $D$. f. erythropterum is restricted to the basin of the River Velika Morava in Serbia. While D. $f$. erythropterum is widespread within Bulgaria (GEORGIEV 2011; TOPALOV et al. 2014), its presence in European Turkey still requires confirmation (ÖZDIKMEN 2010). The eastern range boundary of $D$. f. erythropterum runs along the River Dnipro in Ukraine. All records of D. f. erythropterum from areas east of the Dnipro (BARTENEV 2009) very probably result from a confusion with Dorcadion carinatum igrenum, which also very often has brown 
elytra and red legs. The presence of $D . f$. erythropterum on the Crimean Peninsula (BARTENEV 2009) is unlikely. There are no specimens from Crimea in BARTENEV's collections (deposited in SMNKNU), contrary to his published claims.

Dorcadion fulvum opillicum ssp. nov. is known from several localities in western Ukraine. It is currently unclear whether D. f. opillicum ssp. nov. or D. f. erythropterum is present in neighbouring eastern Poland.

\section{ACKNOWLEDGEMENTS}

I wish to thank Mr. Ruslan PANIN, Mr. Yaroslav KaPELYUKH and Mr. Oleksander KRAVCHENKO for providing additional comparative material for the study.

This study was supported by the Rufford Foundation Small Grants for Nature Conservation: Grant No 21831-1 (2017-2018) Estimation of Soil Coleoptera Extinction Rate in Steppe Remnants of Burshtyn Opillya and Implications for Their Restoration and Conservation.

\section{REFERENCES}

Aistleitner E., Lencina GuttiérRez J.L., Adlbauer K. 2015. Fragmenta entomofaunistica XIX: Faunistische Notizen zu Arten der Gattung Iberodorcadion Breuning, 1943 auf der Iberischen Halbinsel sowie Streudaten der Dorcadiini diverser Provenienz (Coleoptera, Cerambycidae, Lamiinae). Entomofauna, 36 (41): 537-548.

BARTENev O.F. 2009. The longhorn beetles of Eastern Ukraine and Crimea. V.N. Karasin Kharkiv National University Press, Kharkiv. (in Russian)

Brelih S., Drovenik B., Pirnat A. 2006. Material for the Beetle Fauna (Coleoptera) of Slovenia $2^{\text {nd }}$ contribution: Polyphaga: Chrysomeloidea (= Phytophaga): Cerambycidae. Scopolia, 58: $1-442$.

BREuning S. 1946. Nouvelles formes de Dorcadion (Col. Cerambycidæ). Miscellanea Entomologica 43 (8): 91-132.

BREuning S. 1962. Revision der Dorcadionini (Coll. Ceramb.). Abhandlungen und Berichte aus dem staatlichen Museum für Tierkunde in Dresden. Entomologische Abhandlungen, 27: 1-666 (1-48, 49-192, 193-240, 241-336, 337-432, 433-528, 529-665).

Burakowski B. 1957. Occurrence of the species of the genus Dorcadion Dalm. in Poland (Coleoptera, Cerambycidae). Fragmenta Faunistica, 7 (12): 1-7. (in Polish)

Chyubchiк V.Yu. 2010. The annotated list of longicorn-beetles (Coleoptera: Cerambycidae) of Central Moldova. Russian Entomological Journal, 19 (2): 111-118. (in Russian) 
ĆurČić S. B., Brajković M.M., Tomić V.T., Mihajlova B. 2003. Contribution to the knowledge of Longicorn beetles (Cerambycidae, Coleoptera) from Serbia, Montenegro, the Republic of Macedonia and Greece. Archives of Biological Sciences, 55 (1-2): 33-38.

DANILEVSKY M.L. 2019. Catalogue of Palaearctic Cerambycoidea. Electron Version, Updated: 09.04.2019. Internet: http://www.cerambycidae.net/catalog.pdf

DASCAlu M.-M. 2006. Food plant data for several longhorn beetles from Romania (Coleoptera: Cerambycidae). Entomologica Romanica, 11: 9-12.

Dascalu M.-M., CuZEPAn G. \& TĂUȘAN I. 2012. The catalogue of Dorcadionini species (Coeloptera: Cerambycidae) from the Natural History Museum of Sibiu, Romania. Analele Știintififice ale Universității "Alexandru Ioan Cuza” din Iași, s. Biologie animală, LVIII: 77-84.

Dobrosavljević J., Mihajlović L. 2014. Prilog poznavanju faune strižibuba (Coleoptera, Cerambycidae) Srbije, sa osvrtom na zaštićene vrste. Šumarstvo, 1-2: 21-31.

FASUlATI K.K. 1955. Ecological and faunistic revue of Cerambycidae of Zakarpattya. Scientific Notes of Uzhgorod University. Series Biology, 11: 123-133. (in Russian)

GANEv J. 1985. Über die von Dr. Botscharov von Bulgarien gesammelten Cerambycidae-Arten (Coleoptera). Articulata, 2 (6): 147-153.

GASKó B. 1978. Angaben zur Cerambycida-Fauna im Waldstreifen am Szegediner Kreisschutzdamm. A Móra Ferenc Múzeum évkönyve, 79 (1): 425-453. (in Hungarian)

GeORGIEV G. 2011. Species composition of cerambycid fauna (Coleoptera: Cerambycidae) in Western Balkan Range, Bulgaria. Forest Science, 1-2: 69-81.

Georgiev G., Migliaccio E., Doychev D. 2006. Longhorn beetles (Coleoptera: Cerambycidae) in Western Rhodopes (Bulgaria). [in:] P. BERON (ed.). Biodiversity of Bulgaria. 2. Biodiversity of Western Rhodopes (Bulgaria and Greece). I. Pensoft \& National Museum of Natural History, Sofia, 347-360.

Gutowski J.M., HoŁowiński M., Piotrowski W., RozwaŁka R. 1999. New records of Cerambycidae (Coleoptera) from Roztocze, Lublin Upland and Podlasie (E Poland). Wiadomości Entomologiczne, 18 (1): 11-22. (in Polish)

Hegyessy G., KovÁcs T. 1997. The longhorn beetle fauna of Zempléni-Mountains (Coleoptera: Cerambycidae). Folia Historico Naturalia Musei Matraensis, 22: 223-245. (in Hungarian)

Hegyessy G., Kovács T., Muskovits J., Szalóki D. 2000. Data to the longhorn beetle fauna of Budapest and Pest county (Coleoptera: Cerambycidae). Folia Historico Naturalia Musei Matraensis, 24: 221-282. (in Hungarian)

Horvatovich S. 1992. The Cerambycidae (Coleoptera) of Béda-Karapancsa landscape-protection area, South Hungary. Dunántúli Dolgozatok Természettudományi Sorozat, 6: 133-140. (in Hungarian)

Horvatovich S., Hegyessy G., KovÁcs T. 2000. Data to the longhorn beetle fauna of southern part of Dunántúl (Coleoptera: Cerambycidae). Dunántúli Dolgozatok Természettudományi Sorozat, 10: 223-228. (in Hungarian)

ILIĆ N., ĆURČIĆ S. 2015. A checklist of longhorn beetles (Coleoptera: Cerambycidae) of Serbia. Zootaxa, 4026 (1): 1-97. 
IstRATE P. 2005. An ecological survey of the Cerambycidae (Coleoptera) in the geographic basin of the Târnava Mică Valley (Transylvania, Romania). Transylvanian Review of Systematical and Ecological Research, 2: 99-108.

Kovács T., Hegyessy G. 1997. The longhorn beetle fauna of the Mátra Mountains (Coleoptera, Cerambycidae). Folia Historico Naturalia Musei Matraensis, 22: 203-222. (in Hungarian)

Lingafelter S.W., Nearns E.H., Tavakilian G.L., Monné M.Á. \& Biondi M. 2014. Longhorned Woodboring Beetles (Coleoptera: Cerambycidae and Disteniidae) Primary Types of the Smithsonian Institution. Smithsonian Institution Scholarly Press, Washington D.C.

Löbl I., Smetana A. (eds.) 2010. Catalogue of Palaearctic Coleoptera Vol. 6: Chrysomeloidea. Apollo Books, Stenstrup, Denmark.

MÁtÉ A., MerkL O. 2005. Pusztai gyalogcincér (Dorcadion fulvum cervae). Környezetvédelmi és Vízügyi Minisztérium, Természetvédelmi Hivatal.

Merkl O., Hegyessy G., KovÁcs T. 1996. Cerambycidae (Coleoptera) from the Bükk National Park. [in:] S. MAhunkA (ed.). The Fauna of the Bükk National Park, II. Hungarian Natural History Museum, Budapest, 309-326.

Merkl O., Szabó K., Fülöp D., Bozsó M., Máté A., Peregovits L., Soltész Z., Somogyi K., PÉNZES Z. 2007. Dorcadion cervae (Coleoptera: Cerambycidae) - a distinct species or subspecies? [in:] P. BATÁRY, Á. Kớrösi (eds.). Abstract book, Symposium on Conservation and Genesis of the Fauna of the Carpathian Basin "Fauna Pannonica 2007". Hungarian Natural History Museum, Budapest, 44.

Migliaccio E., Georgiev G.T., Gashtarov V. 2007. An annotated list of Bulgarian Cerambycids with special view on the rarest species and endemics (Coleoptera: Cerambycidae). Lambillionea, 107 (1): 1-78

ÖZDIKMEN H. 2010. The Turkish Dorcadiini with zoogeographical remarks (Coleoptera: Cerambycidae: Lamiinae) Munis Entomology \& Zoology Journal, 5 (2): 380-498.

PIL N. 2004/2005. Checklist of longhorn beetles (Coleoptera: Cerambycidae) from Mt. Fruška Gora. Acta Entomologica Serbica, 9/10 (1/2): 105-110.

Pil N., Stankovic M. 2006. Cerambycidae (Coleoptera) of the Zasavica special nature reserve (Serbia). Acta Entomologica Serbica, 11 (1/2): 33-43.

SERAFIM R. 2010. The catalogue of the Palaearctic species of Lamiinae (Coleoptera: Cerambycidae) from the patrimony of "Grigore Antipa" National Museum of Natural History (Bucharest) (Part V). Travaux du Muséum National d'Histoire Naturelle "Grigore Antipa", LIII: 235-272.

Serafim R., Chimisliu C. 2010. Contributions to the knowledge of the diversity of cerambicids (Coleoptera: Chrysomeloidea: Cerambycidae) from Oltenia fauna, Romania. Muzeul Olteniei Craiova. Oltenia. Studii si comunicari. Stiintele Naturii, 26 (2): 112-132.

Serafim R., Maican, S. 2011. Catalogue of Cerambycidae, Megalopodidae and Chrysomelidae (Coleoptera: Chrysomeloidea) recently entered in the patrimony of "Grigore Antipa" National Museum of Natural History (Bucharest). "Igor Ceianu" collection. Travaux du Muséum National d'Histoire Naturelle "Grigore Antipa", LIV (2): 425-460.

Topalov P., Doychev D., Simov N., Sakalian V., Georgiev G. 2014. New records of longhorn beetles (Coleoptera: Cerambycidae) in Vitosha Mountain. Forest Science, 1/2: 95-102. 
Ungureanu V., Maican S., Serafim R. 2008. Diversity of coleopterans: Cerambycidae, Chrysomelidae, Coccinellidae from Buzãu Area (Romania). Travaux du Muséum National d'Histoire Naturelle "Grigore Antipa”, LI: 171-183.

Vukajlović F., Živanović N. 2015. The longhorn beetles (Coleoptera: Cerambycidae) of the city of Kragujevac: Central Serbia. Kragujevac Journal of Science, 37: 149-160.

Zamoroka A.M., Panin R.Yu., Kapelukh Y. I., PodobivskiY S.S. 2012. The catalogue of the longhorn beetles (Coleoptera: Cerambycidae) of western Podillya, Ukraine. Munis Entomology \& Zoology, 7 (2): 1145-1177.

Received: 26 August 2019

Accepted: 28 October 2019 